\title{
Equilibrium sampling reveals increasing thermodynamic potential of polycyclic aromatic hydrocarbons during sewage sludge digestion
}

Sjøholm, Karina Knudsmark; Nørgaard Schmidt, Stine; Jahnke, Annika; Svensmark, Bo; Mayer, Philipp

Published in:

Chemosphere

Link to article, DOI:

10.1016/j.chemosphere.2018.05.104

Publication date:

2018

Document Version

Peer reviewed version

Link back to DTU Orbit

Citation (APA):

Sjøholm, K. K., Nørgaard Schmidt, S., Jahnke, A., Svensmark, B., \& Mayer, P. (2018). Equilibrium sampling reveals increasing thermodynamic potential of polycyclic aromatic hydrocarbons during sewage sludge digestion. Chemosphere, 207, 421-429. https://doi.org/10.1016/j.chemosphere.2018.05.104

\section{General rights}

Copyright and moral rights for the publications made accessible in the public portal are retained by the authors and/or other copyright owners and it is a condition of accessing publications that users recognise and abide by the legal requirements associated with these rights.

- Users may download and print one copy of any publication from the public portal for the purpose of private study or research.

- You may not further distribute the material or use it for any profit-making activity or commercial gain

- You may freely distribute the URL identifying the publication in the public portal 


\section{Equilibrium sampling reveals increasing thermodynamic potential of polycyclic aromatic hydrocarbons during sewage sludge digestion}

Karina K.

jessing@plen.ku.dk

Stine N. Schmidt $t^{\mathrm{a}, \mathrm{b}}$

stnsch@env.dtu.dk

Annika Jahnke

annika.jahnke@ufz.de

Bo Svensmark

svensmark@plen.ku.dk

Philipp

philm@env.dtu.dk

aDepartment of Environmental Engineering, Technical University of Denmark, Bygningstorvet B115, DK-2800, Kgs, Lyngby, Denmark

${ }^{\mathbf{b}}$ Department of Plant and Environmental Sciences, University of Copenhagen, Thorvaldsensvej 40, DK-1871, Frederiksberg, Denmark

${ }^{\mathbf{c}}$ Department of Cell Toxicology, Helmholtz Center for Environmental Research GmbH - UFZ, Permoserstraße 15, DE-04318, Leipzig, Germany

*Corresponding author. Department of Environmental Engineering, Technical University of Denmark, Bygningstorvet B115, DK-2800, Kgs, Lyngby, Denmark

Handling Editor: Keith Maruya

Abstract

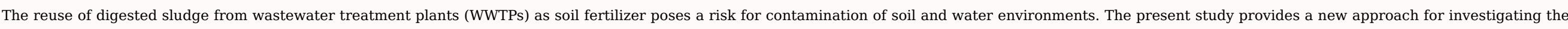

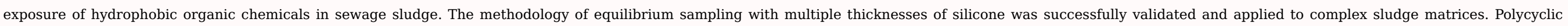

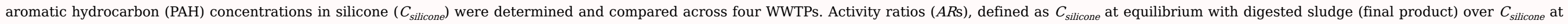

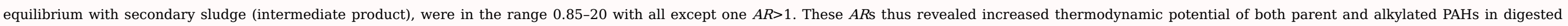

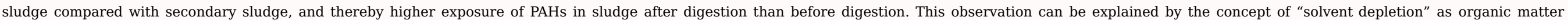

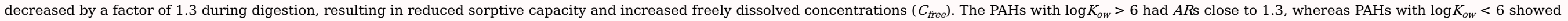
higher $A R$ s than the organic matter decrease factor of 1.3. $C_{\text {free }}$ in digested sludge were higher than reported in rural soil and generally consistent with levels reported for Baltic Sea sediment.

Keywords: Equilibrium sampling; Solvent depletion; Waste reuse; Biosolids; Digestion; Thermodynamic potential

\section{Introduction}

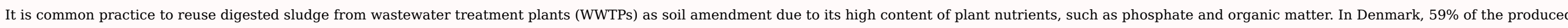

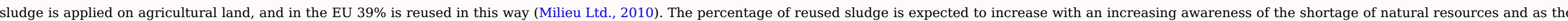

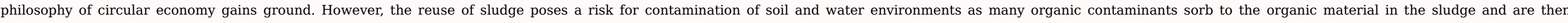
transferred to agricultural land during sludge application (Clarke and Smith, 2011). 


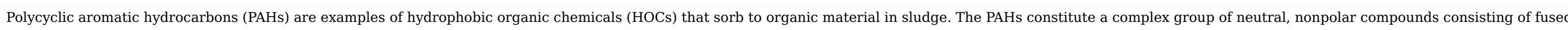

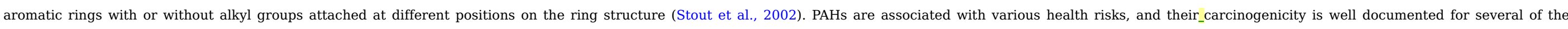

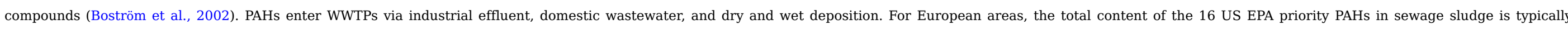

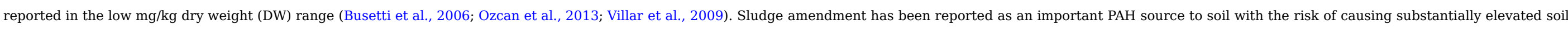

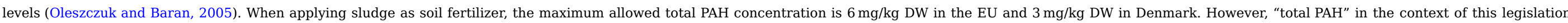
includes only nine PAHs, of which none is alkylated (Milieu Ltd., 2010).

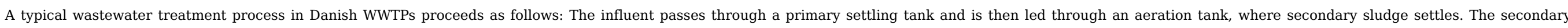

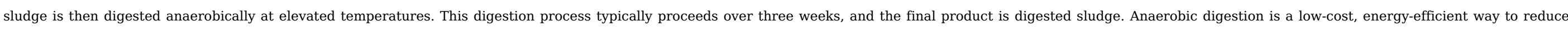

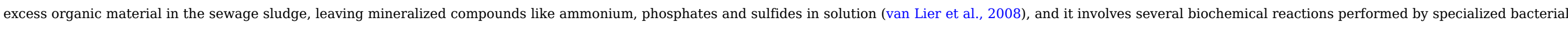

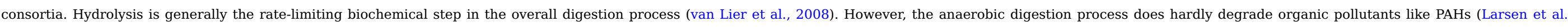

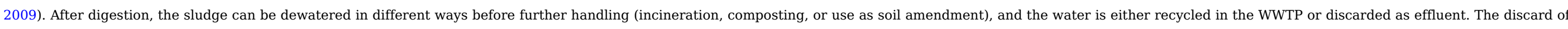

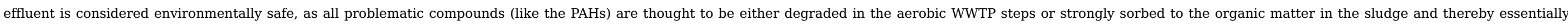
removed from the aqueous phase.

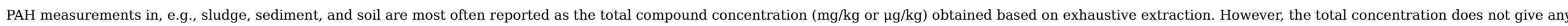

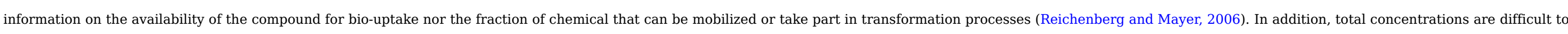

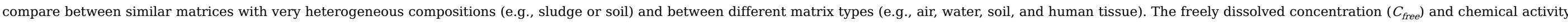

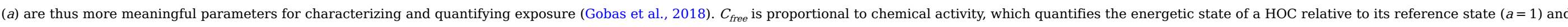

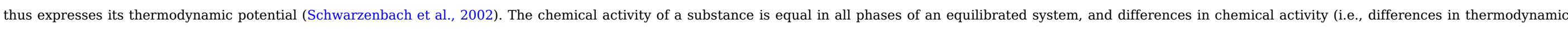

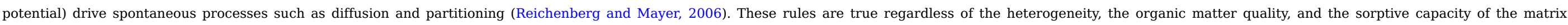

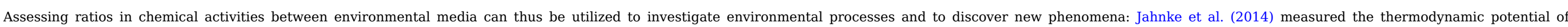

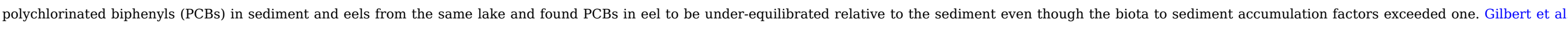

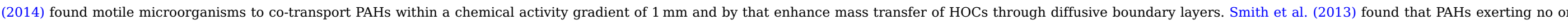

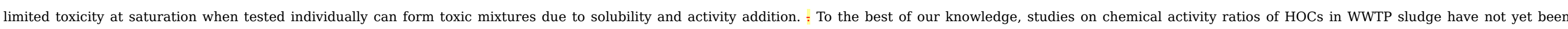
reported.

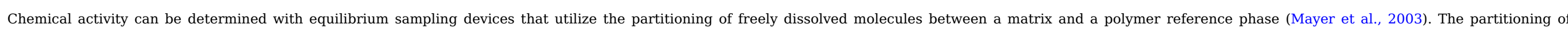

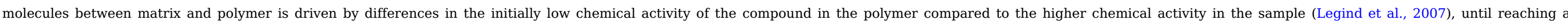
thermodynamic equilibrium (i.e., the same chemical activity in polymer and sample).

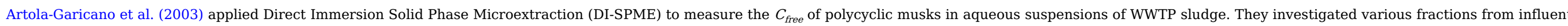

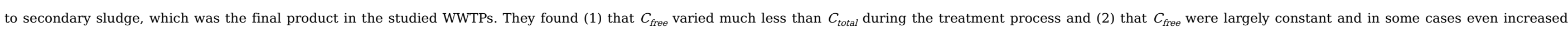

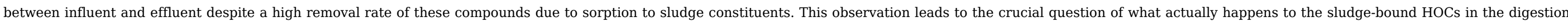

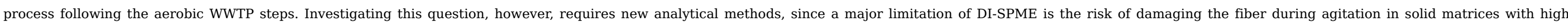
viscosity (Souza-Silva et al., 2015). So far other passive sampling methods have not been used for the analysis of trace contaminants in WWTP sludge (Lindholm-Lehto et al., 2017).

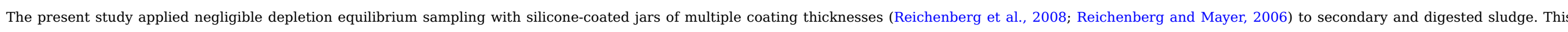

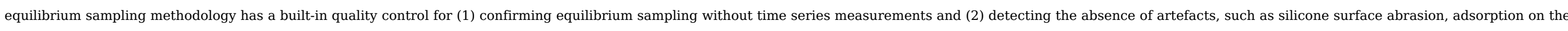

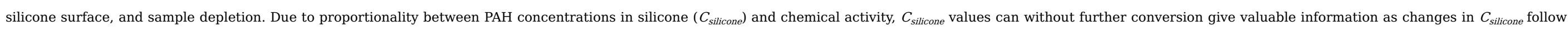
changes in the thermodynamic potential (Reichenberg et al., 2008). Further, $C_{\text {free }}$ can be determined from $C_{\text {silicone }}$ using silicone- and analyte-specific silicone to water partition coefficients ( $K_{\text {silicone, water }}$ ): 


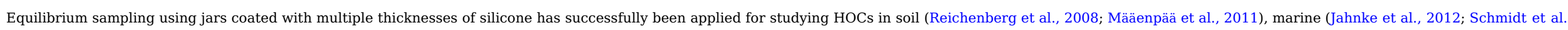
2017), lake (Jahnke et al., 2014), and river sediments (Schäfer et al., 2015).

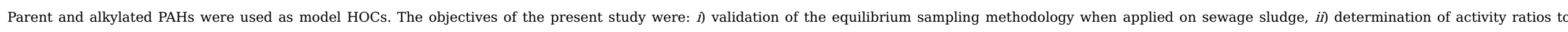

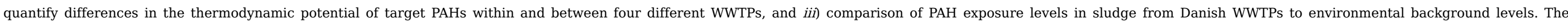

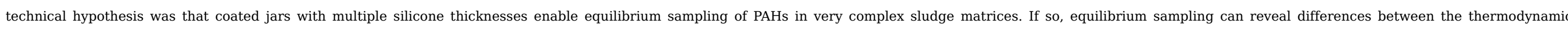

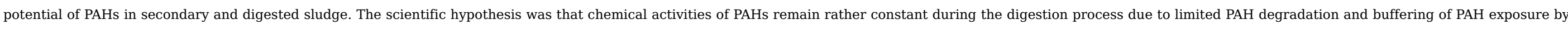
the matrix. Contrarily, decreases in chemical activities would indicate PAH degradation or increased sorption, whereas increasing chemical activities could indicate a decrease in sorptive capacity.

\section{Materials and methods}

\subsection{Chemicals and solvents}

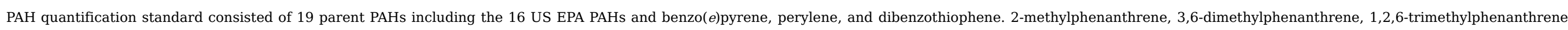

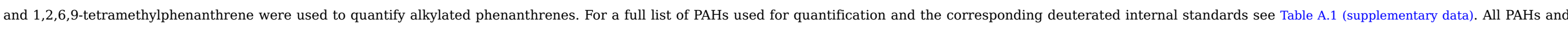

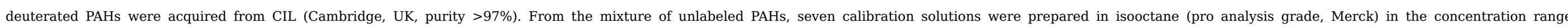

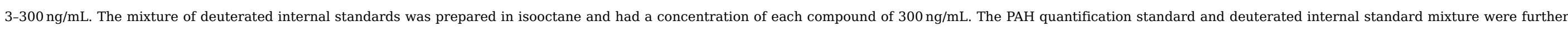
diluted 20 times in ethyl acetate (>99.7\%, Sigma-Aldrich) before addition of $200 \mu \mathrm{L}$ to each of the $4 \mathrm{~mL}$ extracts. The final internal standard concentration was $0.75 \mathrm{ng} / \mathrm{mL}$.

\subsection{Sludge samples}

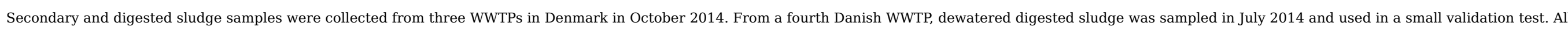

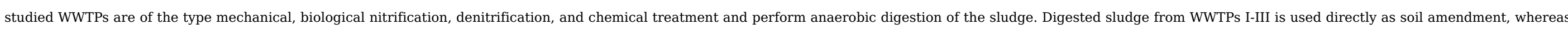

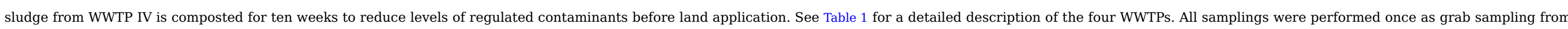

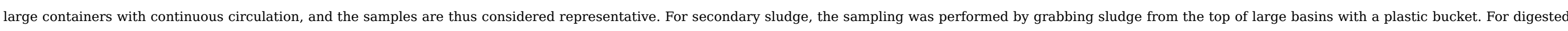

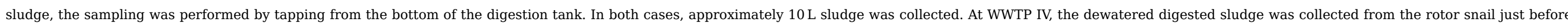

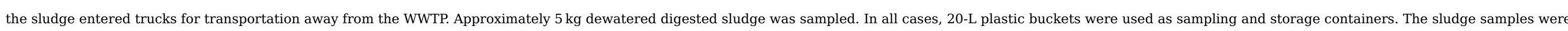

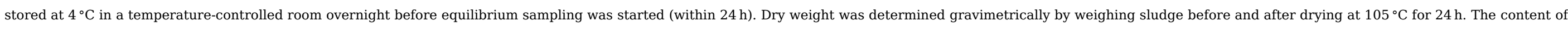
organic matter was determined gravimetrically by weighing sludge before and after loss on ignition of the dried sludge at $550^{\circ} \mathrm{C}$ over night (Nelson and Sommers, 1996 ).

Table 1 Characteristics of the studied WWTPs, total PAH concentrations, and physical parameters

alt-text: Table 1

WWTP Size, PEa:

Catchment area:

PAH concentrations, exhaustive extraction in digested sludge $(\mathrm{mg} / \mathrm{kg} \mathrm{DW})^{\mathrm{b}, \mathrm{c}}$

Sludge sample type:

Physical parameters

Ace Flo Phe Flu Pyr BbF BaP Ipyr BghiP Total PAH

DW $(\%)^{\mathrm{d}} \quad$ Organic matter $(\%)$

200.000

Mixed domestic and industry

0.06

0.78

$0.71-0.76$

$0.43 \quad 0.26$

$0.32 \quad 4.0$

Sec
$420.000 \quad$ Mixed domestic and industry

Secondary

Digested

Secondary

Digested

Secondary
$1.9 \pm 0.35 \quad 66 \pm 0.12$

$3.1 \pm 0.08 \quad 52 \pm 0.12$

$1.7 \pm 0.01 \quad 73 \pm 0.63$

$4.5 \pm 0.01 \quad 62 \pm 0.13$

$2.2 \pm 0.15 \quad 68 \pm 0.20$ 


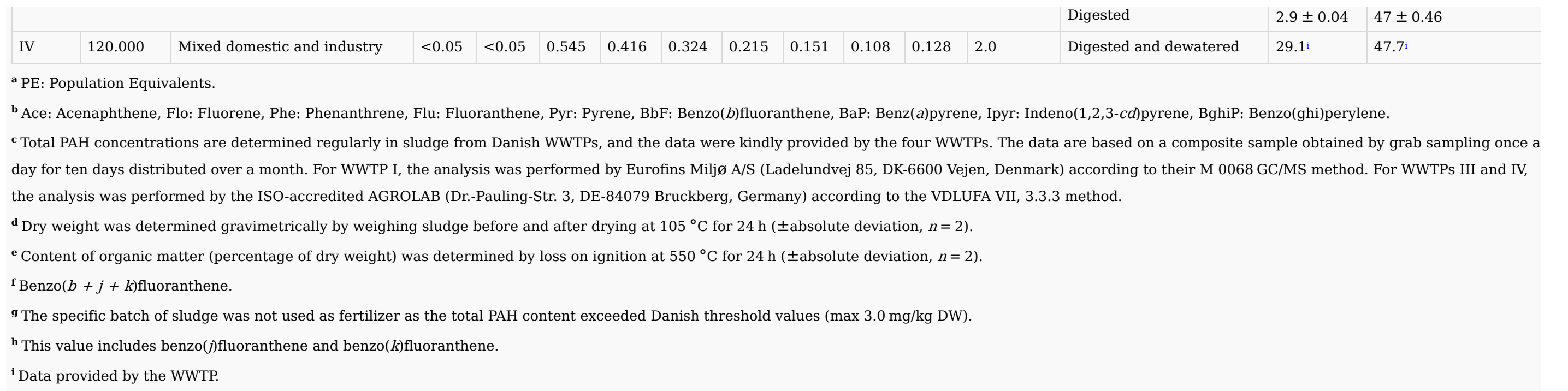

\subsection{Equilibrium sampling}

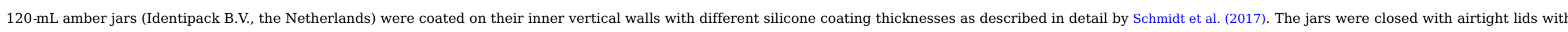

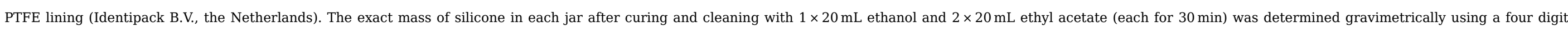
balance. The corresponding average silicone thicknesses were $2.5 \pm 0.2 \mu \mathrm{m}(n=9), 4.1 \pm 0.4 \mu \mathrm{m}(n=12), 7.2 \pm 0.5 \mu \mathrm{m}(n=9)$, and $13.5 \pm 1.1 \mu \mathrm{m}(n=11)$, respectively.

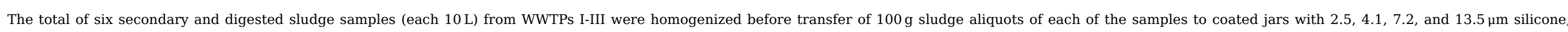

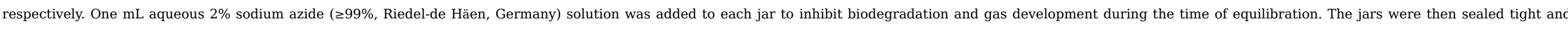

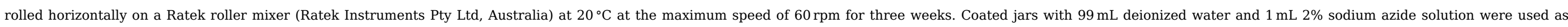
controls and treated like the jars with sludge.

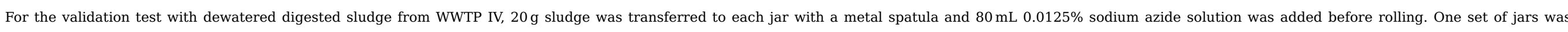

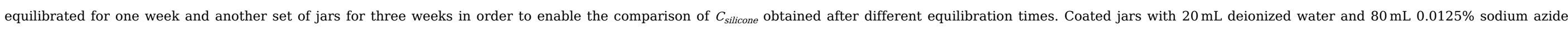
solution served as controls for this test.

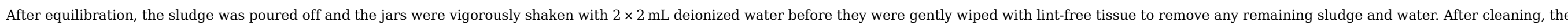

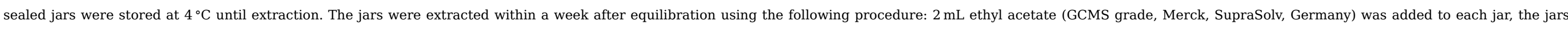

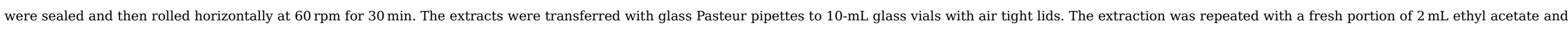
the extracts were combined and stored at $-80^{\circ} \mathrm{C}$ until chemical analysis.

\subsection{Chemical analysis}

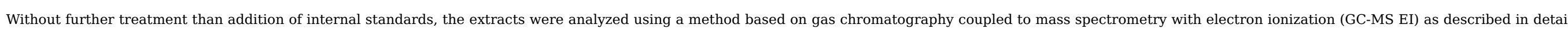

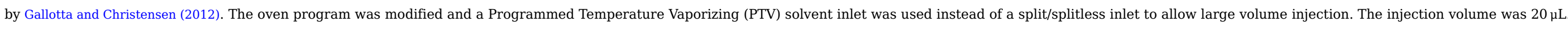

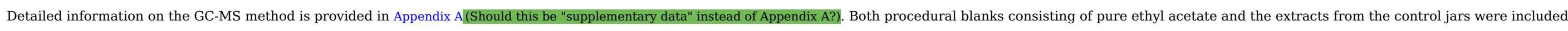
in the chemical analysis.

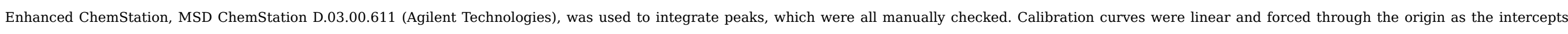




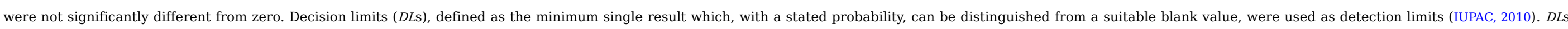
were calculated using the formula:

$$
D L=\frac{t_{\alpha, d . f ., 1} \times s}{a}
$$

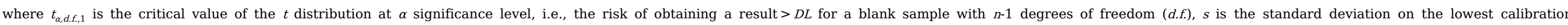

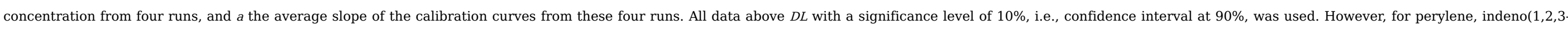

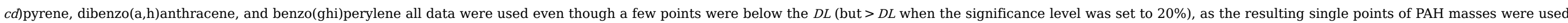
in the function PAH mass plotted versus silicone mass subjected to quality control, as described in section 3.1. below. $D L s$ ( $\alpha=10 \%$ ) ranged from 0.03 to $1.99 \mathrm{ng} / \mathrm{jar}$ (see all $D L \mathrm{~s}$ in Table A.2, supplementary data).

\subsection{Determination of $K_{\mathrm{p}}$ values}

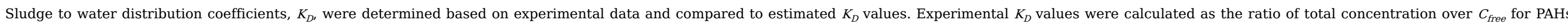

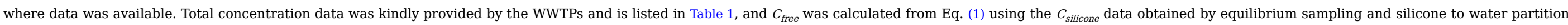
coefficients by Humel et al. (2017).

$K_{D}$ values were estimated using the equation:

$$
\mathrm{K}_{\mathrm{D}}=\mathrm{f}_{\mathrm{oc}} \times \mathrm{K}_{\mathrm{oc}}
$$

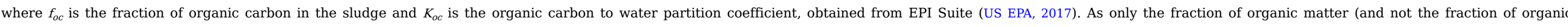

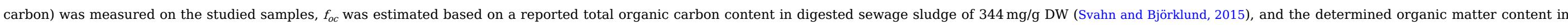

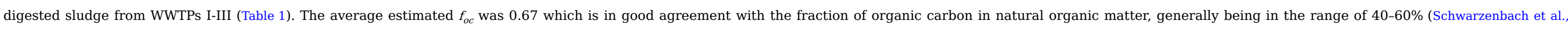
2002).

\section{Results and discussion}

\subsection{Method validation}

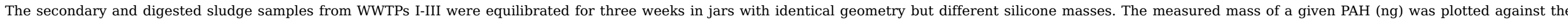

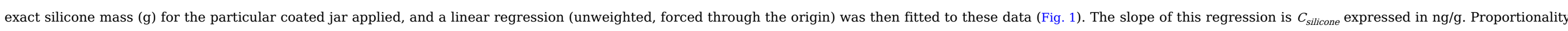

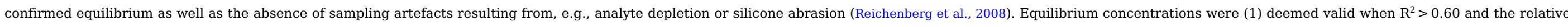

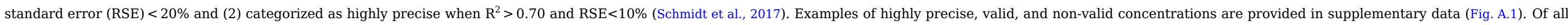
determined concentrations, $83 \%$ were deemed valid and of these $71 \%$ were categorized as highly precise. 

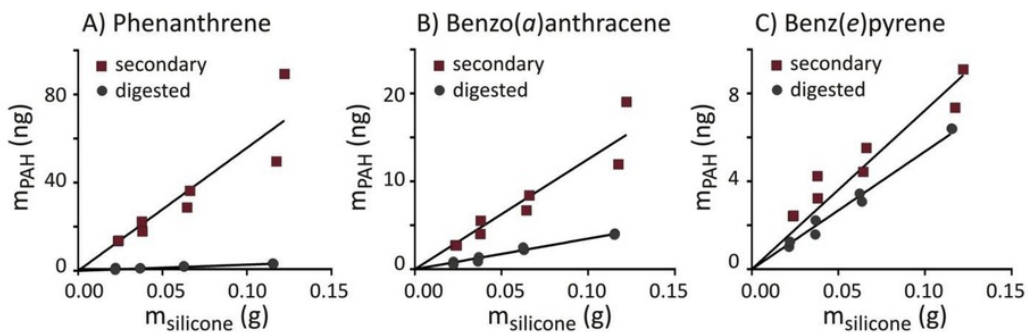

\begin{tabular}{|c|c|c|c|}
\hline$C_{\text {silicone }}(\mathrm{ng} / \mathrm{g})$ & $\begin{array}{l}-\quad 558.1 \pm 56.0 \\
\text { - } 27.7 \pm 1.4\end{array}$ & $\begin{array}{c}\text { - } 125.3 \pm 10.4 \\
\text { - } 34.8 \pm 1.0\end{array}$ & $\begin{array}{l}\text { - } \quad 72.3 \pm 4.4 \\
\text { - } 53.6 \pm 1.7\end{array}$ \\
\hline $\mathrm{R}^{2}$ & $\begin{array}{ll}-\quad & 0.81 \\
-\quad & 0.94\end{array}$ & $\begin{array}{ll}\text { - } & 0.86 \\
-\quad & 0.98\end{array}$ & $\begin{array}{ll}- & 0.86 \\
- & 0.98\end{array}$ \\
\hline RSE (\%) & $\begin{array}{c}10.0 \\
-\quad 4.9\end{array}$ & $\begin{array}{l}\text { - } \quad 8.3 \\
-\quad 2.8\end{array}$ & $\begin{array}{l}6.1 \\
3.1\end{array}$ \\
\hline
\end{tabular}

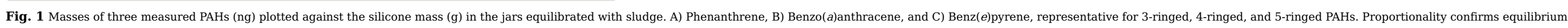

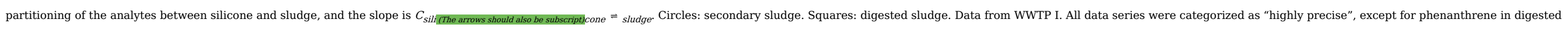
sludge which was categorized as "valid". $C_{\text {silic (The arrows should also be subscript)one }}=$ sludge \pm SEM (ng/g), $\mathrm{R}^{2}$ and RSE (\%) for the shown data are provided below the graph.

\section{alt-text: Fig. 1}

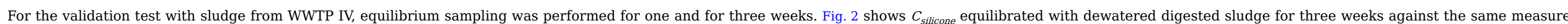

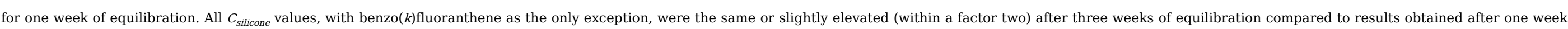

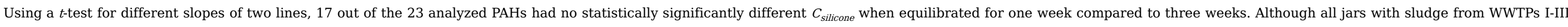

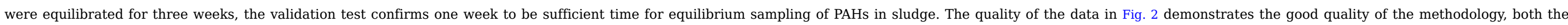
equilibrium sampling and the chemical analysis.

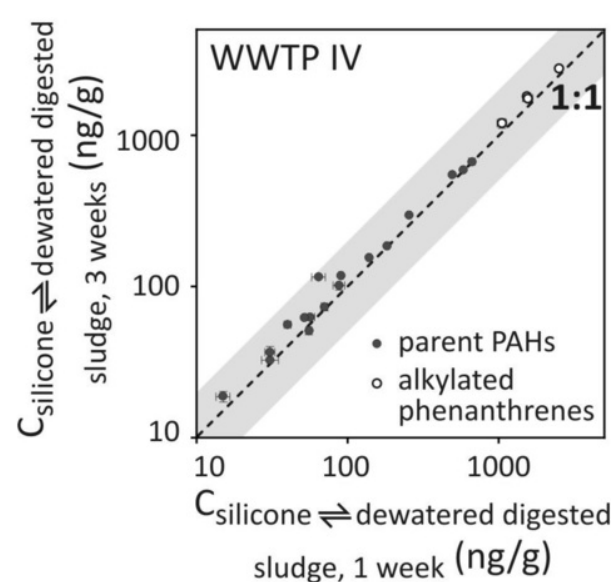

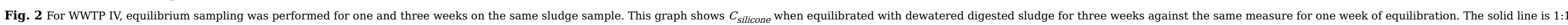

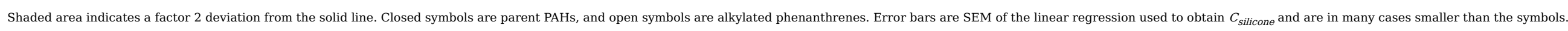

\section{alt-text: Fig. 2}

\subsection{Thermodynamic levels and activity ratios of PAHs}




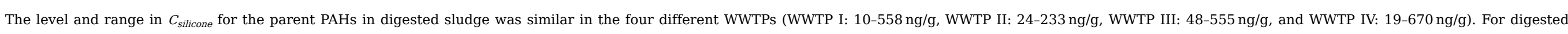

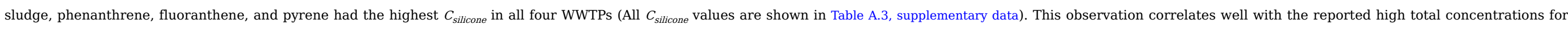

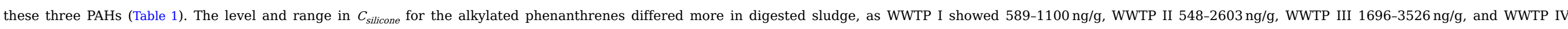

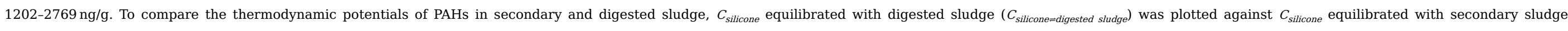
( $\left.C_{\text {silicone=secondary sludge }}\right)$ in Fig. 3 (results from WWTP I-III). The activity ratio $(A R)$ was defined as:

$$
A R=\frac{C_{\text {silicone } \rightleftharpoons \text { digested sludge }}}{C_{\text {silicone } \rightleftharpoons \text { secondary sludge }}}
$$

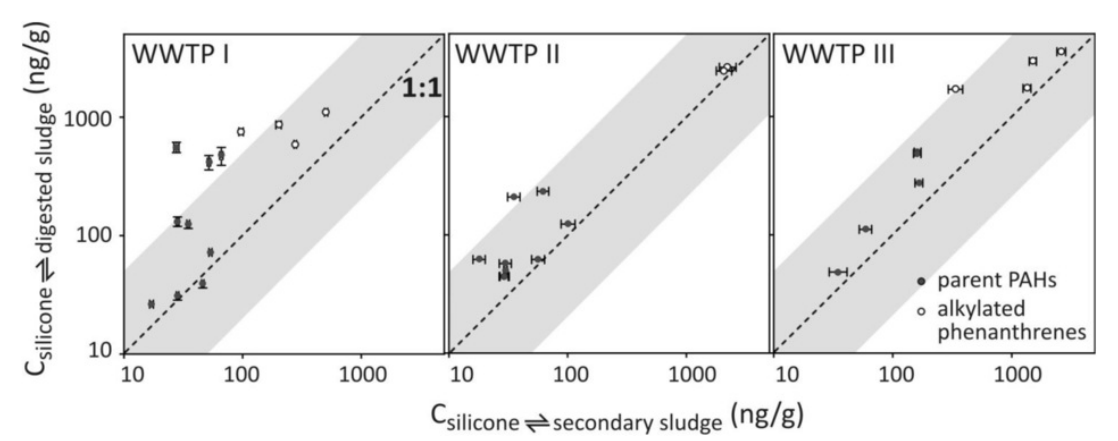

Fig. 3 Activity ratios (ARs) of parent (closed symbols) and alkylated (open symbols) PAHs for three Danish WWTPs, presented as $C_{\text {sili }}$

$=$ digested sludge against $C_{\text {silicon_[The arrows should also be subscripte }} \rightleftharpoons$ secondary sludge. The solid lines indicate equal ARs in

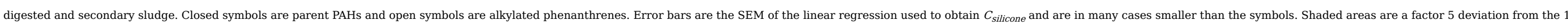
line.

alt-text: Fig. 3

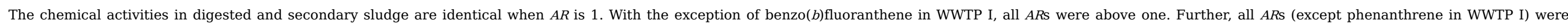

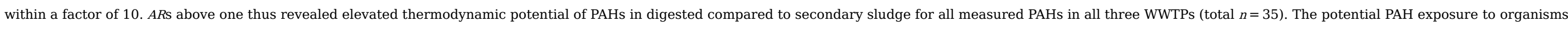

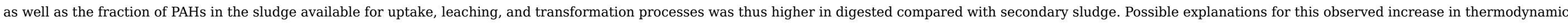

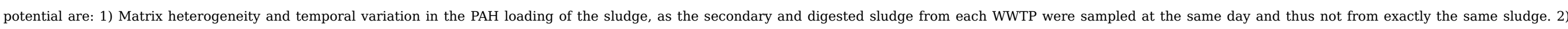

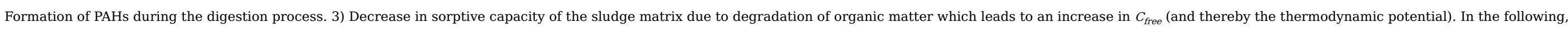
these possible explanations are discussed:

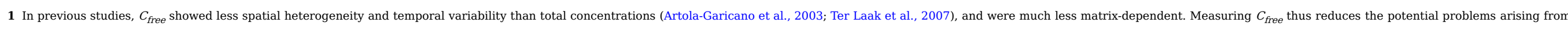

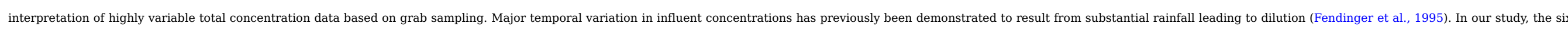

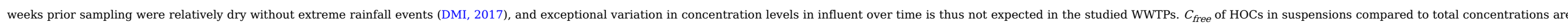

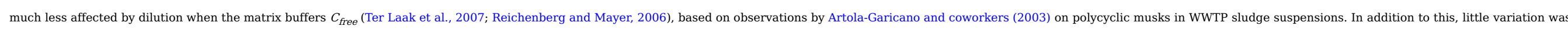

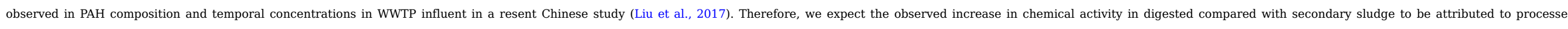
occurring during the digestion process rather than temporal variations in influent concentrations. Furthermore, the increased ARs are a consistent observation for all PAHs in all three WWTPs.

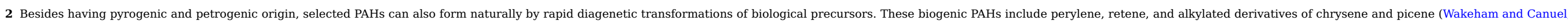
2016). However, the increase in $A R$ s in the present study was observed for all measured PAHs and not exclusively for perylene, the only biogenic PAH that was measured.

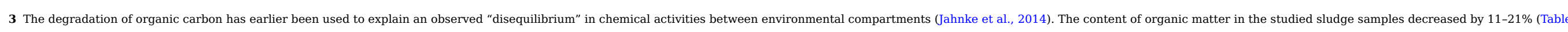

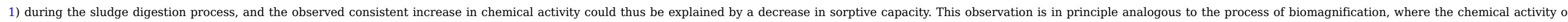




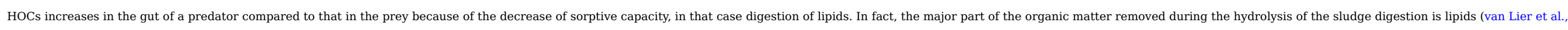

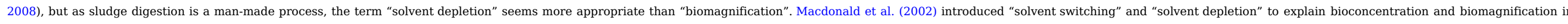

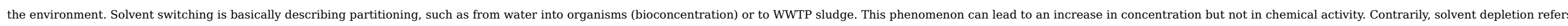

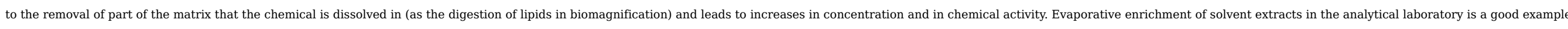

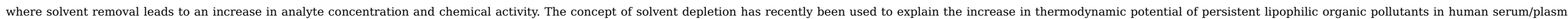

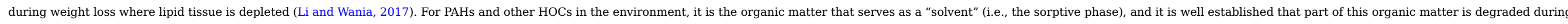
the sludge digestion process (van Lier et al., 2008). The observed declines in organic matter (Table 1) and simultaneous increases in chemical activity (Fig. 3) during sludge digestion are in excellent agreement with the solvent depletion concept.

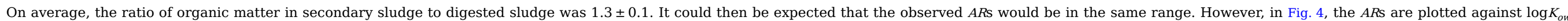
showing the highest $A R$ s for the less hydrophobic PAHs ( $\left.\log K_{o w}<6\right)$ and $A R$ s close to 1.3 for the more hydrophobic PAHs $\left(\log K_{o w}>6\right)$.

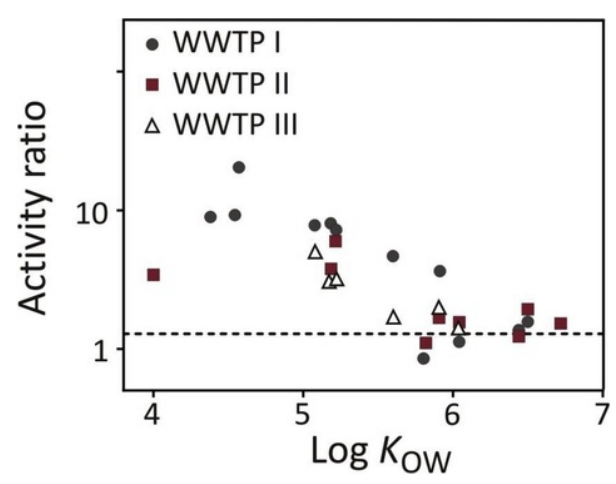

Fig. 4 Activity ratio $(A R)$ as a function of the analyte $\log K_{o W}$ (Mackay et al., 2006) for WWTPS I-III (total $n=27$ ). The broken line is 1.3 which corresponds to the secondary:digested organic matter ratio. alt-text: Fig. 4

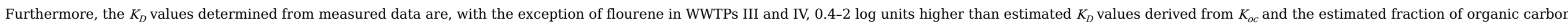

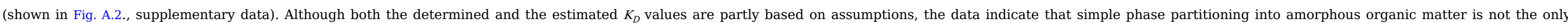

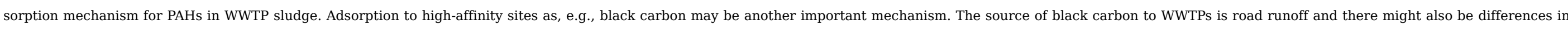

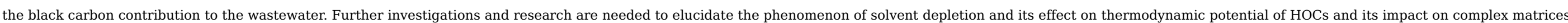
such as sewage sludge, which consist of several different sorptive phases (including lipids, amorphous carbon, black carbon, and dissolved organic carbon).

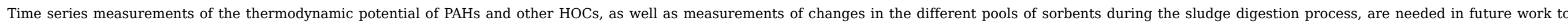

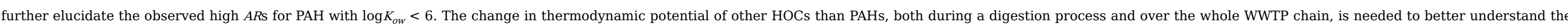

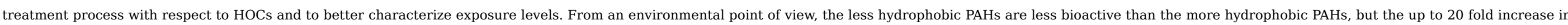
exposure concentrations in a matrix which is commonly used as soil amendment needs further investigation and consideration.

\subsection{Comparison of freely dissolved PAH concentrations in digested sludge to environmental background levels}

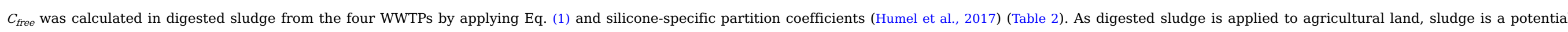

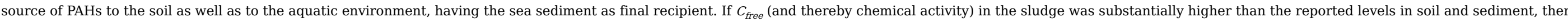

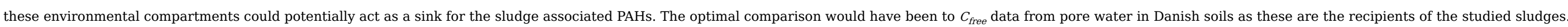

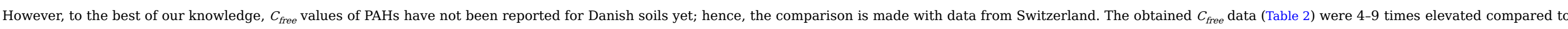

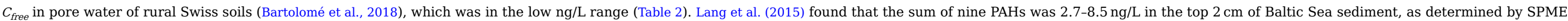




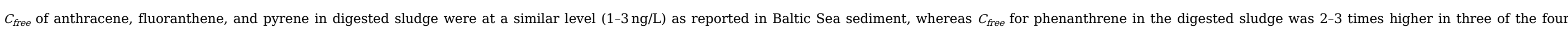

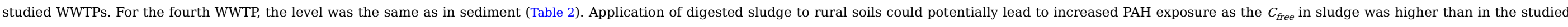

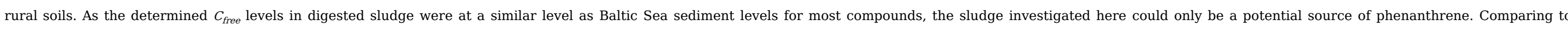

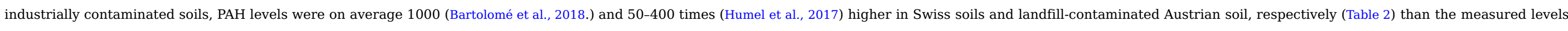
in the digested sludge.

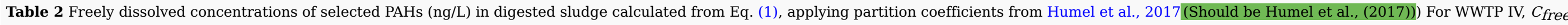
from both one and three weeks of equilibration are included in the table.

alt-text: Table 2

\begin{tabular}{|c|c|c|c|c|}
\hline \multirow[t]{2}{*}{ Location } & \multicolumn{4}{|c|}{$C_{\text {free }}(\mathrm{ng} / \mathrm{L})$} \\
\hline & Phenanthrene & Anthracene & Fluoranthene & Pyrene \\
\hline WWTP I, 3 weeks & 9.1 & 1.2 & 2.4 & 2.0 \\
\hline WWTP II, 3 weeks & 2.2 & 0.8 & 1.1 & 1.1 \\
\hline WWTP III, 3 weeks & 9.1 & 1.0 & 2.6 & 2.3 \\
\hline WWTP IV, 1 week & 8.0 & 0.9 & 3.0 & 3.2 \\
\hline WWTP IV, 3 weeks & 9.0 & 1.5 & 3.1 & 3.2 \\
\hline Baltic Sea sediment, close to Denmark ${ }^{\mathrm{a}}$ & 3.9 & 0.8 & 2.2 & 1.7 \\
\hline Baltic Sea sediment, inner Gulf of Bothniaa & 2.9 & 0.2 & 0.6 & 0.3 \\
\hline Swiss rural soilb & 1.7 & nd & 0.28 & 0.35 \\
\hline Swiss skeet-contaminated soil ${ }^{b}$ & 2220 & 115 & 1500 & 969 \\
\hline Austrian landfill contaminated soilc & 386 & 138 & 1012 & 755 \\
\hline
\end{tabular}

a Data from Lang et al. (2015).

b Data from Bartolomé et al. (2018).

c Data from Humel et al. (2017).

\section{Conclusion}

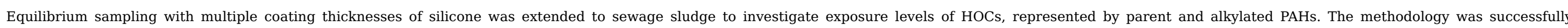

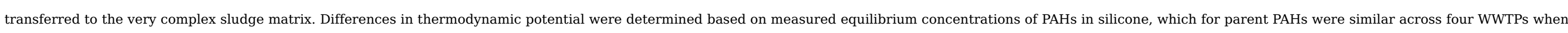

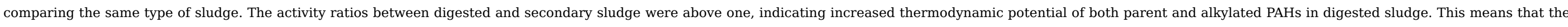

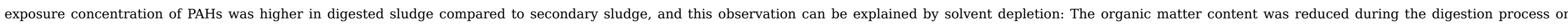

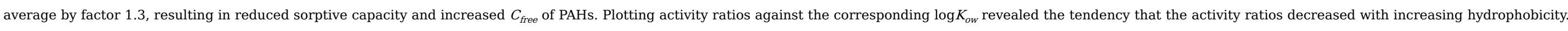

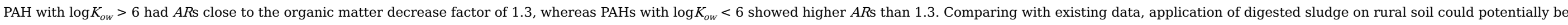

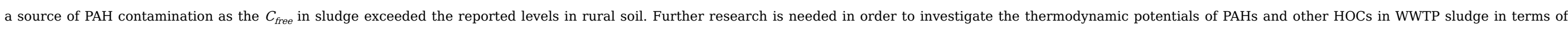
elucidating phenomena such as solvent depletion and to address the fate of HOCs in the soil environments receiving the sludge.

\section{Acknowledgement}




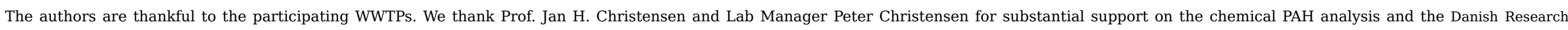
Council, Technology and Production for funding (Grant no.: DFF 1337-00033).

\section{Appendix A. Supplementary data}

Supplementary data related to this article can be found at https://doi.org/10.1016/j.chemosphere.2018.05.104.

\section{References}

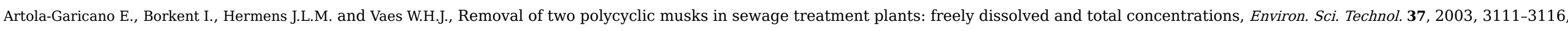
https://doi.org/10.1021/es020226x.

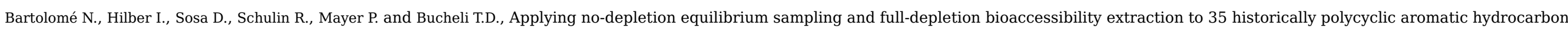
contaminated soils, Chemosphere 199, 2018, 409-416.

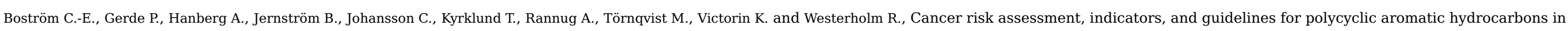
the ambient air, Environ. Health Perspect. 110, 2002, 451-488 https://doi.org/10.1289/ehp.02110s3451.

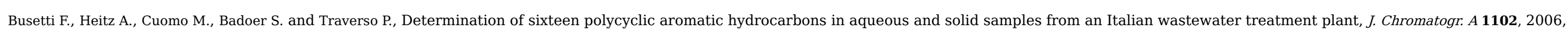
104-115 https://doi.org/10.1016/j.chroma.2005.10.013.

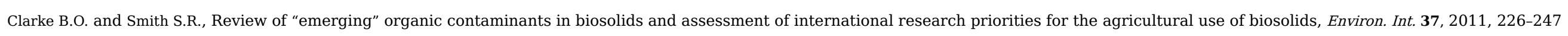
https://doi.org/10.1016/j.envint.2010.06.004.

DMI, Danish Weather Archive, 2017, [WWW Document] https://www.dmi.dk/vejr/arkiver/vejrarkiv.

Fendinger N.J., Begley W., McAvoy D. and Eckhoff W., Measurement of alkyl ethoxylate surfactants in natural waters, Technology 29, 1995, 856-863, https://doi.org/10.1021/es00004a004.

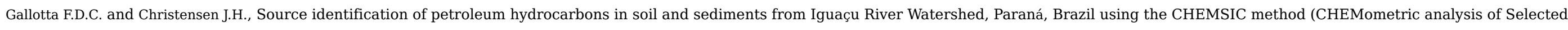
Ion Chromatograms), J. Chromatogr. A 1235, 2012, 149-158 https://doi.org/10.1016/j.chroma.2012.02.041.

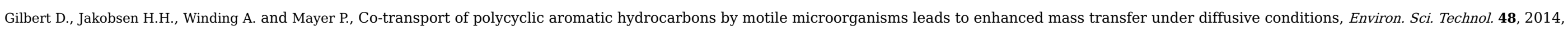
4368-4375 https://doi.org/10.1021/es404793u.

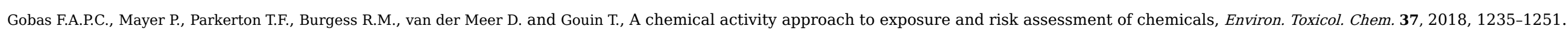

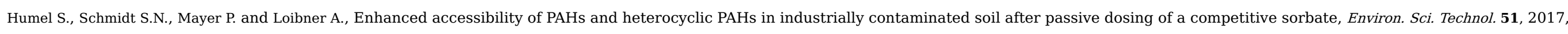
8017-8026 https://doi.org/10.1021/acs.est.7b01198.

IUPAC, Chemical Compendium ("The Gold Book"), 2010.

Jahnke A., Mayer P. and McLachlan M.S., Sensitive equilibrium sampling to study polychlorinated biphenyl disposition in Baltic Sea sediment, Environ. Sci. Technol. 46, 2012, 10114-10122 https://doi.org/10.1021/es302330v.

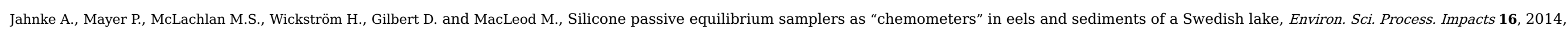
464-472 https://doi.org/10.1039/c3em00589e.

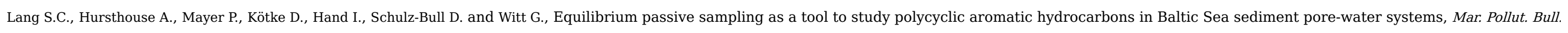
101, 2015, 296-303 https://doi.org/10.1016/j.marpolbul.2015.10.069. 
Larsen S.B., Karakashev D., Angelidaki I. and Schmidt J.E., Ex-situ bioremediation of polycyclic aromatic hydrocarbons in sewage sludge, J. Hazard Mater. 164, 2009, 1568-1572 https://doi.org/10.1016/j.jhazmat.2008.08.067.

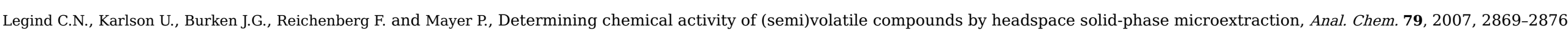
https://doi.org/10.1021/ac061880o.

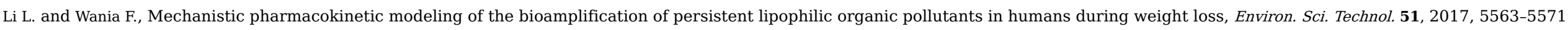
https://doi.org/10.1021/acs.est.7b00055.

Lindholm-Lehto P.C., Ahkola H.S.J. and Knuutinen J.S., Procedures of determining organic trace compounds in municipal sewage sludge-a review, Environ. Sci. Pollut. Res. 24, 2017, 4383-4412 https://doi.org/10.1007/s11356-016-8202-z.

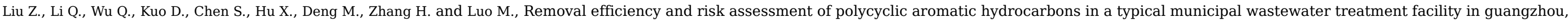
China, Int. J. Environ. Res. Publ. Health 14, 2017, 861 https://doi.org/10.3390/ijerph14080861.

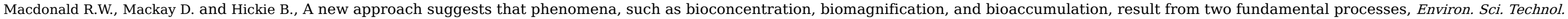
December 2002, 456-462, https://doi.org/10.1021/es022470u.

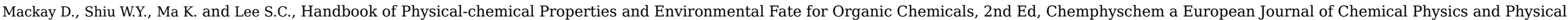
Chemistry, 2006, Taylor \& Francis Group, LLC; FL, USA.

Mayer P., Tolls J., Hermens J.L.M. and Mackay D., Equilibrium sampling devices, Environ. Sci. Technol. 2003, May, 184A-191A.

Milieu Ltd, Environmental, Economic and Social Impacts of the Use of Sewage Sludge on Land Final Report Part II: Report on Options and Impacts, 2010.

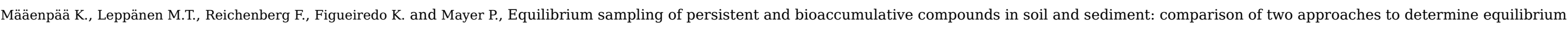
partitioning concentrations in lipids, Environ. Sci. Technol. 45, 2011, 1041-1047 https://doi.org/10.1021/es1029969.

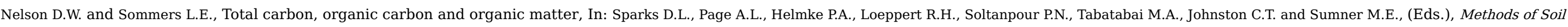
Analysis, Part 3 Chemical Analysis, 1996, Soil Science Society of America, Inc.; Madison.

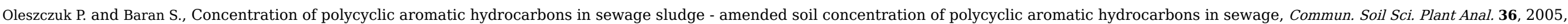
1083-1097 https://doi.org/10.1081/CSS-200056865.

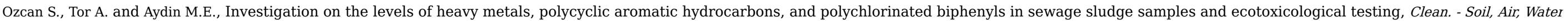
41, 2013, 411-418 https://doi.org/10.1002/clen.201100187.

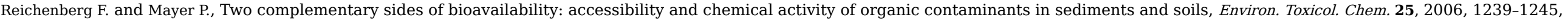
https://doi.org/10.1897/05-458R.1.

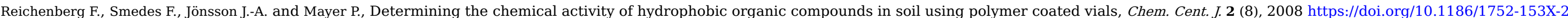
8.

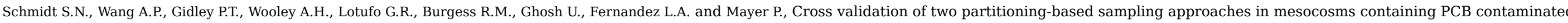
field sediment, biota, and activated carbon amendment, Environ. Sci. Technol. 51, 2017, 9996-10004 https://doi.org/10.1021/acs.est.7b01909.

Schwarzenbach R.P., Gschwend P.M. and Imboden D.M., Environmental Organic Chemistry, 2002, John Wiley \& Sons, Inc; Hoboken, NJ, USA https://doi.org/10.1002/0471649643. 


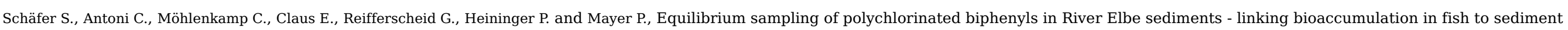
contamination, Chemosphere 138, 2015, 856-862 https://doi.org/10.1016/j.chemosphere.2015.08.032.

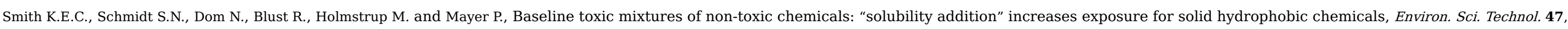
2013, 2026-2033 https://doi.org/10.1021/es3040472.

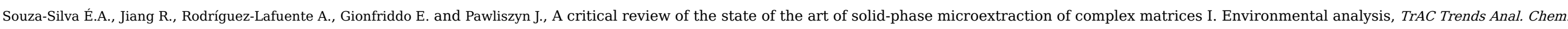
(Reference Ed.) 71, 2015, 224-235 https://doi.org/10.1016/j.trac.2015.04.016.

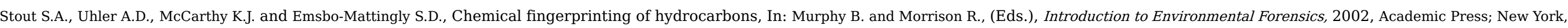
$135-260$.

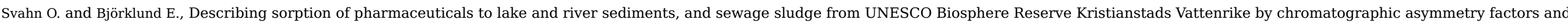
recovery measurements, J. Chromatogr. A 1415, 2015, 73-82 https://doi.org/10.1016/j.chroma.2015.08.061.

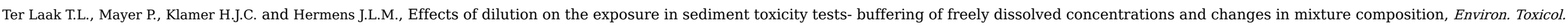
Chem. 26, 2007, 2187-2191 https://doi.org/10.1897/07-113R.1.

US EPA, Estimation Programs Interface SuiteTM for Microsoft巴 Windows, 2017 v. 4.11.

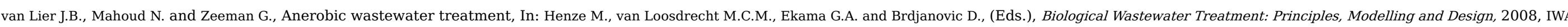
Publishing; London, U.K, 401-442.

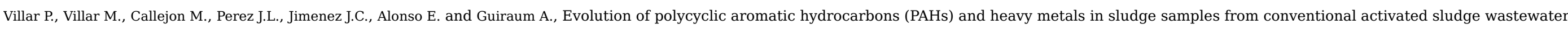
treatment plants, Environmetrics 20, 2009, 561-574 https://doi.org/10.1002/env.

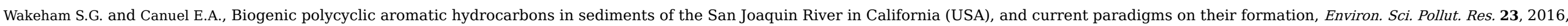

10426-10442 https://doi.org/10.1007/s11356-015-5402-x.

\section{Appendix A. Supplementary data}

The following is the supplementary data related to this article:

Multimedia Component 1

Multimedia component 1

alt-text: Multimedia component 1

\section{Graphical abstract}




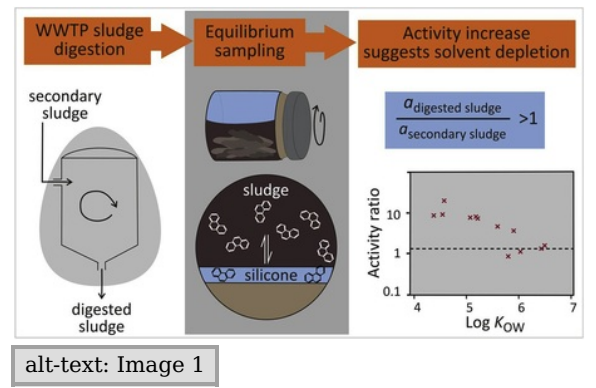

\section{Highlights}

- Equilibrium sampling with multiple thicknesses of silicone was applied on sludge.

- Exposure of PAHs was higher in digested compared to secondary sludge.

- Solvent depletion is suggested to cause increasing $C_{\text {free }}$ during digestion.

- The activity ratios of PAHs decreased with increasing hydrophobicity.

- $C_{\text {free }}$ rural soil $<C_{\text {free }}$ sludge $=C_{\text {free }}$ marine sediment $<C_{\text {free }}$ contaminated soil.

\section{Queries and Answers}

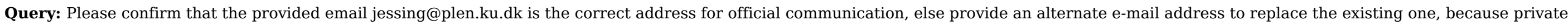
e-mail addresses should not be used in articles as the address for communication.

Answer: Please change my email address to kaknje@env.dtu.dk

Query: Please check the address for the corresponding author that has been added here, and correct if necessary.

Answer: Correct

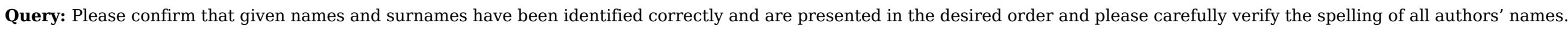

Answer: All names are correct and presented in the right order.

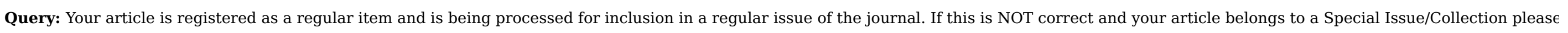
contact p.das@elsevier.com immediately prior to returning your corrections.

Answer: Regular issue is correct 